\title{
Inhalt - Contents, Vol. 19, No. 5, 1992
}

\section{Originalarbeiten}

Meßfehler bei der Bestimmung von Elektrol-ytkonzen-trationen mit ionenselektiven Elektroden (ISE) bei Anwesenheit von anorganischen oder metabolisierbaren Anionen

\section{Zander, $\mathrm{R} \quad 221$}

Uberlegenheit der Gelzentrifugation bei Antikörpersuchtest und -identifízierung

Kretschmer, V., Heuckeroth, A., Schulzki, T., Dietrich, G 226

Wirkung verschiedener Plasmapräparationen und i.v.-Immunglobuline auf die Funktion von

Lymphozyten und Monozyten in vitro

Sibrowski, W., Brauer, P.

232

Anti-Apo-B-Sepharose-4B CL-induzierte In-vitro-Komple-mentaktivierung: Hemmung durch Antikoagulation

Kadar, J.G., Parusel, M., Borberg, H 237

Auswirkungen der Leukozytenfilltration auf die Komple-mentaktivierung in gelagerten

Vollblutkonserven

Schleuning, M., Utz, H., Heim, M., Mempel, W.

Entstehung und Verteilung von Anaphylatoxinen während In-vitro-LDL-Apherese

Parusel, M., Kadar,J.G., Borberg, H 245

Thrombozytapherese mit Vivacell BT798 DEA, Haemonetics V-50 und PCS-Plus:

Samntlungseffizienz und Produktqualität bei identischen Spendern

Richter, E., Pawlow, I., Krause, K.-P, Matthes, G

249

Evaluierung des Haemonetics V 50 -«Time Saver»-Protokolis

Soudavar, E, Borberg, H

Original Paper

Sources of Error in Measuring Electrolyte Concentrations by Means of Ionselective Electrodes (ISE) in the Presence of Inorganic or Metabolizable Anions

Zander, R 221

Superiority of Gel Centrifugation in Antibody Screening and Identification

Kretschmer, V, Heuckeroth, A., Schulzki, T., Dietrich, G 226

Effect of Different Plasma Preparations and i.v. Immuno-globulins on the Function of

Lymphocytes and Monocytes in vitro

Sibrowski, W., Brauer, P. 232

Anticoagulation-Dependent Inhibition of in vitro Complement Activation by Anti-Apo-B

Sepharose 4B CL

Kadar,J.G, Parusel, M., Borberg, H 237

Effects of Leukocyte Depletion on the Formation of Anaphylatoxins in Stored Whole Blood

Schleuning, M., Utz, H., Heim, M., Mempel, W. 242

Anaphylatoxin Generation and Distribution During in vitro LDL Apheresis 
Parusel, M., Kadar, J.G., Borberg, H 245

Platelet Apheresis with Vivacell BT798 DEA, Haemonetics V-50 and PCS-Plus: Preparation Efficiency and Product Quality Using Identical Donors

Richter, E., Pawlow, I., Krause, K.-P., Matthes, G 249

Evaluation of the Haemonetics V 50 - Time Saver Protocol

Soudavar, E, Borberg, $\mathrm{H} \quad 253$

Kurzmitteilungen

Internationale Standardisierung von Produktcodes

Weißhaar, D., Kreutzig, B

Short Communications

International Standardization of Product Codes

258 Weißhaar, D., Kreutzig, B

258

Impressum 219

Inhaltsverzeichnis 220

Buchbesprechungen 262

Hinweise für Autoren 263

Imprint 219

Contents 220

Book Reviews 262

Instructions to Authors

263

Bibliographischer Hinweis: Inhaltsverzeichnisse dieser Zeitschrift erscheinen regelmäßig in current contents ${ }^{\circledR}$ sowie in anderen bibliographischen Diensten. 